\title{
Efficacy of colposcopy technique with Pap smear and histology in screening of cervical lesions
}

\author{
Smitha Krishnegowda ${ }^{1}$, Veena $\mathrm{MS}^{2}$ \\ ${ }^{1}$ Assistant Professor, Department of Obstetrics \& Gynecology, KIMS Hospital, Bangalore, Karnataka, India \\ ${ }^{2}$ Senior Specialist, Community Health Centre, Jayanagar, Mysore, Karnataka, India
}

Received: 30 July 2014

Accepted: 9 August 2014

\section{*Correspondence:}

Dr. Smitha Krishnegowda,

E-mail: smithakeshava@gmail.com

(C) 2014 Krishnegowda $\mathrm{S}$ et al. This is an open-access article distributed under the terms of the Creative Commons Attribution Non-Commercial License, which permits unrestricted non-commercial use, distribution, and reproduction in any medium, provided the original work is properly cited.

\begin{abstract}
Background: In India the most common genital cancer among women is carcinoma of the cervix (80\%). The objective of the study is analysis of efficacy of colposcopy technique with Pap smear and histology in screening of cervical lesions.

Methods: Patients above 18 years of age with varied parity and socioeconomic status attending out-patient clinics were studied for correlation between cytology, colposcopy and colposcopically directed biopsy for a one year period.

Results: In cytology and colposcopic directed biopsy sensitivity is $81 \%$, specificity is $95 \%$, false positive is $4.9 \%$, false negative is $18 \%$ and accuracy is $92 \%$. In colposcopy and directed biopsy sensitivity is $94 \%$, specificity is $91 \%$, false positive is $7.4 \%$, false negative is $5.8 \%$ and accuracy is $92.85 \%$. Colposcopy helps to reduce false negative cases seen in cytology.

Conclusions: In our study overall incidence of CIN was 19, among them CIN1 in 9\%, CIN2 in 4\%, CIN3 in $4 \%$ and malignancy in $2 \%$ cases. Higher sensitivity in colposcopy and directed biopsy $94 \%$, higher specificity $95 \%$ in cytology as compared to colposcopy. This emphasizes the use of all 3 methods Papincolaou cytology, colposcopy and histology is complementary to each other and helps to reduce false negative cases.
\end{abstract}

Keywords: Carcinoma cervix, Papincolaou cytology, Colposcopy, Colposcopically directed biopsy, Cyto-histology correlation and colposcopy and colposcopic guided biopsy correlation

\section{INTRODUCTION}

Cervical cancer ${ }^{3}$ is the second most frequent cancer in women and ranks $3^{\text {rd }}$ among all cancers in human. It accounts for the $15 \%$ of all female cancers. It contributes to approximately $10 \%$ of worldwide tumor burden and up to $20-30 \%$ of all female cancers in developing countries.

In India the most common genital cancer among women $(80 \%)$ is carcinoma cervix. The lack of established cytological procedure has resulted in the increase in incidence of carcinoma cervix.

Mean age of carcinoma cervix is 47 years, with the distribution of number of patient's bimodal, fairly between the age groups 35-39 years and 60-64 years. There is a trend towards increasing stage with increasing age suggesting that older patients are not being screened as often as younger patients.

Colposcopy used with pap smear as an adjunct to cervical cytology to enhance the diagnostic capabilities in women with an abnormal papincolaou test which can be confirmed by histopathological report forms gold standard in diagnosing carcinoma cervix.

\section{Aims and objective of the study}

1. To screen for cervical neoplasia. 
2. To determine reliability of colposcopy by correlating the findings of colposcopy with cytology and colpscopic directed biopsy in cervical lesions and with symptomatic patients.

\section{METHODS}

\section{Source of data}

Patients with cervical lesions or with symptoms of vaginal discharge, postcoital bleeding and other gynecological problems attending outpatient department of obstetrics \& gynecology, KIMS, Hubli during the period of one year.

Patients above 18 years of age with varied parity and socioeconomic status having following criteria.

\section{Inclusion criteria}

1. Suspicious symptoms like leucorrhea, postcoital or intermenstrual bleeding and postmenopausal bleeding

2. Suspicious cervix such as hypertrophied, Unhealthy cervix, cervix with erosion which bleeds on touch.

3. Abnormal cytology report apparently healthy cervix.

\section{Exclusion criteria}

1. Acute cervical infections

2. Pregnant women

3. Teenage girls

4. Post radiation

5. Invasive cancer of cervix

\section{Procedure}

Patients included in the study were evaluated by noting history, general physical examination, and local examination of (cervix and vagina) perineum. Patients were counseled and procedure explained. Patient put in dorsal position. Cervix visualized with Sims speculum and anterior vaginal wall retractor. Smear taken from the cervix using Ayer's spatula by applying slight pressure on the cervix and rotating through $360^{\circ}$ in squamo columnar junction. Material spread evenly on a glass slide and fixed it with cytofix containing 95\% ethyl alcohol and air dried. Slide was stained with papanicoloau technique. Papanicolaou smears reported as in Bethesda system (2001).

Colposcopy performed without anesthesia. Cervix, vulva, vagina visualized using the Cusco's speculum. First normal saline applied to cervix to remove excessive mucous and green filter used to appreciate vascular pattern. Then $3 \%$ acetic acid applied. Findings were noted in Odell's diagrams in which colposcopic lesions represented in a circular diagram in relation to the external os.
In presence of infection, colposcopy was done after treating infection in a later date. Colposcopic directed biopsy tissue sent for histopathological examination after fixing tissue in $10 \%$, formalin solution. Histological diagnosis was made according to criteria of WHO histological classification of carcinoma cervix.

\section{RESULTS}

Figure 1 shows age distribution of patients.

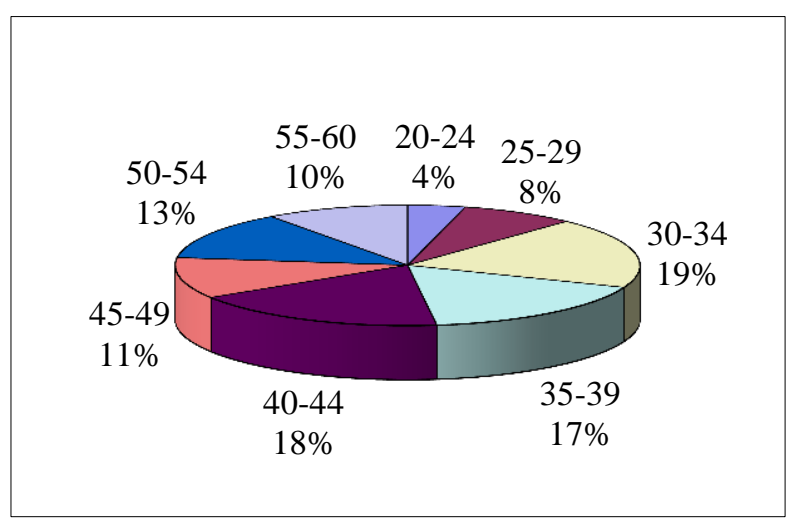

Figure 1: Age distribution of patients.

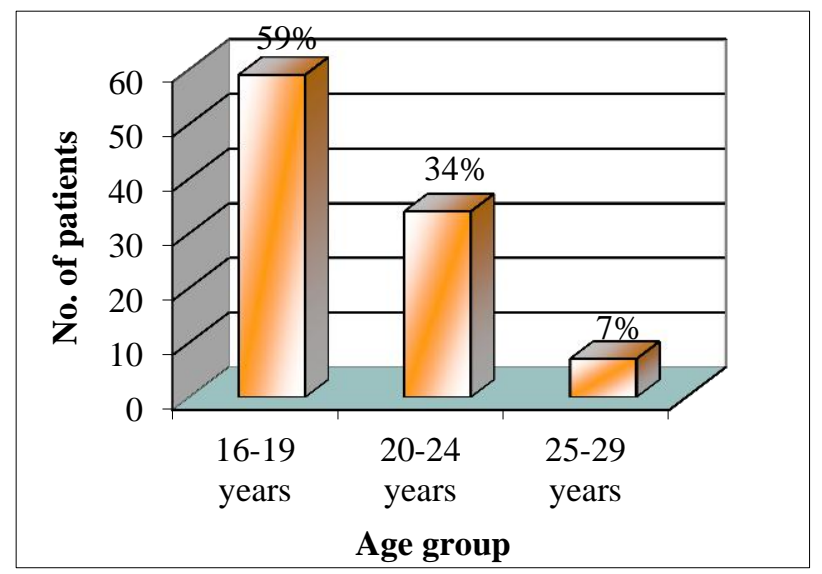

Figure 2: Age at marriage.

Table 1: Type of smears.

\begin{tabular}{|ll|l|}
\hline Types of smears & $\begin{array}{l}\text { No. of } \\
\text { patients }\end{array}$ & Percentage \\
\hline Normal & 10 & $10 \%$ \\
\hline Inflammatory & 63 & $63 \%$ \\
\hline $\begin{array}{l}\text { Inflammation with } \\
\text { squamous metaplasia }\end{array}$ & 5 & $5 \%$ \\
\hline Trichomoniasis & 1 & $1 \%$ \\
\hline $\begin{array}{l}\text { Trichmoniasis with } \\
\text { squamous metaplasia }\end{array}$ & 2 & $2 \%$ \\
\hline LSIL & 8 & $8 \%$ \\
\hline HSIL & 9 & $9 \%$ \\
\hline Invasive carcinoma & 2 & $2 \%$ \\
\hline
\end{tabular}


Table 2: Indications for colposcopy.

\begin{tabular}{|lll|}
\hline Indications & $\begin{array}{l}\text { No. of } \\
\text { patients }\end{array}$ & Percentage \\
\hline Clinically suspicious cervix & 20 & $20 \%$ \\
\hline Chronic white discharge P/v & 30 & $30 \%$ \\
\hline Suspicious cervix/discharge & 35 & $35 \%$ \\
\hline Intermenstrual bleeding & 4 & $4 \%$ \\
\hline Post-coital bleeding & 6 & $6 \%$ \\
\hline Post-menopausal bleeding & 5 & $5 \%$ \\
\hline Miscellaneous & 5 & $5 \%$ \\
\hline Total & 100 & $100 \%$ \\
\hline
\end{tabular}

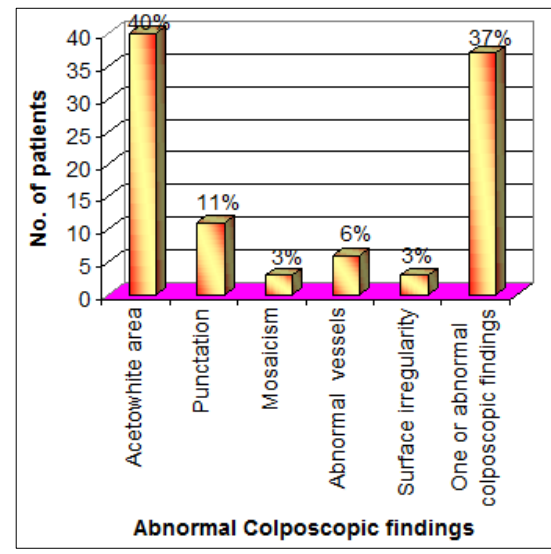

Figure 3: Abnormal colposcopic findings.
Table 3: Coloposcopic diagnosis.

\begin{tabular}{|lll|}
\hline Diagnosis & $\begin{array}{l}\text { No. of } \\
\text { patients }\end{array}$ & Percentage \\
\hline Normal & 11 & 11 \\
\hline Squamous metaplasia & 13 & 13 \\
\hline Chronic cervicities & 28 & 28 \\
\hline CIN 1 & 18 & 18 \\
\hline CIN 2 & 10 & 10 \\
\hline CIN 3 & 6 & 6 \\
\hline Invasive carcinoma & 5 & 5 \\
\hline Unsatisfactory & 9 & 9 \\
\hline Total & 100 & 100 \\
\hline
\end{tabular}

Table 4: Histological diagnosis.

\begin{tabular}{|lll|} 
Histological diagnosis & $\begin{array}{l}\text { No. of } \\
\text { patients }\end{array}$ & Percentage \\
\hline Normal & 8 & $8 \%$ \\
\hline Inflammatory & 68 & $68 \%$ \\
\hline CIN 1 & 10 & $10 \%$ \\
\hline CIN 2 & 6 & $6 \%$ \\
\hline CIN 3 & 6 & $6 \%$ \\
\hline Invasive carcinoma & 2 & $2 \%$ \\
\hline Total & 100 & $100 \%$ \\
\hline
\end{tabular}

Table 5: Cytological correlation with age at marriage.

\begin{tabular}{|c|c|c|c|c|c|c|c|c|}
\hline \multirow{3}{*}{$\begin{array}{l}\text { Age at } \\
\text { marriage }\end{array}$} & \multirow{3}{*}{$\begin{array}{l}\text { No. of } \\
\text { patients }\end{array}$} & \multicolumn{7}{|c|}{ Cytology findings } \\
\hline & & \multirow{2}{*}{ Normal } & \multirow{2}{*}{ Inflammatory } & \multirow{2}{*}{ Trichomoniasis } & \multicolumn{3}{|l|}{ SIL } & \multirow{2}{*}{$\begin{array}{l}\text { Invasive } \\
\text { carcinoma }\end{array}$} \\
\hline & & & & & LSIL & HSIL & HSIL & \\
\hline $16-19$ & 59 & 5 & 42 & 2 & 3 & 5 & 2 & 2 \\
\hline $20-24$ & 34 & 4 & 21 & 1 & 3 & 5 & 4 & - \\
\hline $25-29$ & 7 & 1 & 5 & - & - & 1 & - & - \\
\hline Total & 100 & 10 & 68 & 3 & 6 & 11 & 6 & 2 \\
\hline
\end{tabular}

Table 6: Correlation between cytology and colposcopically directed biopsy.

\begin{tabular}{|lllllllll|}
\hline \multirow{2}{*}{$\begin{array}{l}\text { Cytology findings } \\
\text { No. of }\end{array}$} & $\begin{array}{l}\text { Histopathology report } \\
\text { patients }\end{array}$ & Normal & Inflammatory & CIN & & Invasive \\
\cline { 6 - 8 } & 10 & 5 & 4 & CIN1 & CIN2 & CIN3 & carcinoma \\
\hline Inflammatory & 63 & 3 & 57 & 2 & 0 & & - \\
\hline Infl+Sq metaplasia & 7 & - & 6 & 0 & - & 0 & - \\
\hline Trichomonisis & 1 & - & 1 & - & - & 0 & - \\
\hline LSIL & 8 & - & 3 & 5 & - & - & - \\
\hline HSIL & 9 & - & 1 & 0 & 4 & 4 & 0 \\
\hline Invasive carcinoma & 2 & - & - & - & - & - & 2 \\
\hline Total & 100 & 9 & 74 & 8 & 5 & 4 & 2 \\
\hline
\end{tabular}


Table 7: Correlation between colposcopy and directed biopsy.

\begin{tabular}{|c|c|c|c|c|c|c|c|}
\hline \multirow{3}{*}{ Colposcopy findings } & \multirow{3}{*}{$\begin{array}{l}\text { No. of } \\
\text { patients }\end{array}$} & \multicolumn{6}{|c|}{ Histopathology report } \\
\hline & & \multirow{2}{*}{ Normal } & \multirow{2}{*}{ Inflammatory } & \multicolumn{3}{|l|}{ CIN } & \multirow{2}{*}{$\begin{array}{l}\text { Invasive } \\
\text { carcinoma }\end{array}$} \\
\hline & & & & CIN1 & CIN2 & CIN3 & \\
\hline Normal & 15 & 6 & 9 & - & - & 0 & - \\
\hline Sq metaplasia & 17 & 2 & 13 & 2 & 0 & - & - \\
\hline Chr. cervicitis & 38 & 2 & 34 & 2 & 0 & 0 & - \\
\hline CIN1 & 10 & - & 3 & 7 & - & 0 & - \\
\hline CIN 2 & 5 & - & 1 & - & 4 & 0 & 0 \\
\hline CIN3 & 4 & - & 0 & - & 0 & 4 & 0 \\
\hline Invasive carcinoma & 2 & - & 0 & - & - & - & 2 \\
\hline Unsatisfactory & 9 & 1 & 8 & - & - & - & - \\
\hline Total & 100 & 11 & 73 & 6 & 4 & 4 & 2 \\
\hline
\end{tabular}

\section{DISCUSSION}

In Total 100 cases were selected with different cervical lesions for the study. Majority of the women attending our out patients clinics were low socioeconomic group, uneducated from surrounding villages.

\section{Age of the patient}

Majority of the patients i.e. $36 \%$ were between $30-40$ years of age. Similar observations were made by other authors as follows:

Table 8: Age of the patient.

\begin{tabular}{|c|c|}
\hline Author & Age of the patient \\
\hline Krislma Algotar ${ }^{2}$ (2004) & $31-40$ years \\
\hline Allan B. maclean ${ }^{7}(1985)$ & mean $25-35$ years \\
\hline M. Coppleson ${ }^{8}$ (1985) & mean age $30-39$ years \\
\hline Kasper et al. $^{9}(1970)$ & mean age $25-45$ years \\
\hline
\end{tabular}

Age at the onset of sexual intercourse and the number of years of sexual activity may be related to the development of cervical dysphasia. Most probably the sperm penetration of cervical epithelium may have mutagenic property over the cervical epithelium cells (Coppleson and Reid, 1967). ${ }^{1}$

\section{Distribution of patients according to age at marriage}

Majority of them got married before the age of $19 y$ rs. i.e., $59 \%$ because of the high rate of illiteracy, low socioeconomic status and at the most at 25 years of age.

\section{Distribution of patients according to presenting symptoms}

Out of 100 patients, $68(68 \%)$ of the patients presents with leucorrhea

Study by Bharani Bharti (2003) ${ }^{10}$ and Krislma Algotar $(2004)^{2}$ reported as follows:
Table 9: Distribution of patients according to presenting symptoms.

\begin{tabular}{|ll|}
\hline $\begin{array}{l}\text { Symptoms } \\
\text { Bharani Bharti (2003) }\end{array}$ & $\begin{array}{c}\text { Distribution } \\
\text { of patients }\end{array}$ \\
\hline Vaginal discharge & $12 \%$ \\
\hline $\begin{array}{l}\text { Post-coital bleeding \& other menstrual } \\
\text { irregularities }\end{array}$ & $15 \%$ \\
\hline Krislma Algotar (2004) & \\
\hline White discharge & $42 \%$ \\
\hline $\begin{array}{l}\text { Menstrual irregularities (post-coital } \\
\text { bleeding, postmenstrual bleeding) }\end{array}$ & $4 \%$ \\
\hline
\end{tabular}

Distribution of abnormal colposcopic findings: study by Bharani $^{10}$ reported as follows:

Table 10: Distribution of abnormal colposcopic findings.

\begin{tabular}{|ll|}
\hline Abnormal colposcopic findings \\
\hline Acetowhite epithelium & $22 \%$ \\
\hline Punctation & $6 \%$ \\
\hline Mosaic & $9.2 \%$ \\
\hline Abnormal vessels & $2 \%$ \\
\hline
\end{tabular}

\section{Diagnosis of abnormal colposcopic findings}

In this study $37 \%$ of the cases had one or more abnormal colposcopic findings. Study by Adolf Stafl $^{11}$ as follows:

Table 11: Diagnosis of abnormal colposcopic findings.

\begin{tabular}{|ll|}
\hline Abnormal colposcopic findings \\
\hline Normal & $26 \%$ \\
\hline CIN I & $41 \%$ \\
\hline CIN II & $20 \%$ \\
\hline CIN III & $10 \%$ \\
\hline Invasive carcinoma & $1.2 \%$ \\
\hline
\end{tabular}




\section{Cytology incidence of dysplasia}

Table 12: Cytology incidence of dysplasia.

\begin{tabular}{|llll|}
\hline Author & SIL & CIS & $\begin{array}{l}\text { Invasive } \\
\text { carcinoma }\end{array}$ \\
\hline Present study & $34 \%$ & $6 \%$ & $5 \%$ \\
\hline Adolf Stafl $^{11}$ & $61 \%$ & $18 \%$ & $2.8 \%$ \\
\hline Van Nagell et al. $^{13}$ & $41 \%$ & - & $4.5 \%$ \\
\hline Krislma Algotar $^{2}$ Bombay $^{12}$ & $15.71 \%$ & $1.43 \%$ & $1.43 \%$ \\
\hline Rehka Sapkal $^{12}$ & $13 \%$ & - & $0 \%$ \\
\hline
\end{tabular}

\section{Histological incidence of CIN}

Table 13: Histological incidence of CIN.

\begin{tabular}{|c|c|c|c|}
\hline Author & CIN & CIS & $\begin{array}{l}\text { Invasive } \\
\text { carcinoma }\end{array}$ \\
\hline Present study & $22 \%$ & $6 . \%$ & $5 \%$ \\
\hline Van Nagell et al. ${ }^{13}$ & $27 \%$ & - & $3 \%$ \\
\hline Adolf Stafl $^{11}$ & $52 \%$ & $20 \%$ & $2 \%$ \\
\hline Mridul Gehlot ${ }^{6}$ & $12 \%$ & - & $7 \%$ \\
\hline Krislma Algotar $^{2}$ & $14.29 \%$ & - & $5.71 \%$ \\
\hline
\end{tabular}

\section{Frequency of cancer detection by colposcopy}

Table 14: Frequency of cancer detection by colposcopy.

\begin{tabular}{|ll|}
\hline Author & Frequency \\
\hline Present study & $5 \%$ \\
\hline Kirkup $^{14}$ & $4 \%$ \\
\hline Krislma Algotar $^{2}$ & $2.8 \%$ \\
\hline Stafl \& Mattingly $^{11}$ & $2.8 \%$ \\
\hline
\end{tabular}

\section{Relation of clinical impression of cervix with SIL}

Out of 17 cases of SIL, 8 were having cervical erosion constituting $47 \%$ in present series. This is the commonest cervical finding in cases of SIL. No incidence of SIL noted in healthy cervix, SIL noted in atrophic cervix $(5 \%)$. In chronic cervicitis incidence of SIL was $11 \%$. In chronic hypertrophy and cervical polyp incidence of SIL was $5 \%$.

According to M. S. Nanvati et al., ${ }^{5}$ chronic SIL is $13 \%$; According to Fromint-Smith et al. ${ }^{17}$ suspicious cervix shows SIL in $40 \%$.

This shows that clinical impression of cervix is no guide towards actual pathology of cervix. It is true that higher incidence of SIL and malignancy is associated with erosion, chronic cervicitis and hypertrophy. The pathology observed in clinically healthy looking cervix cannot be overlooked. This stresses the point that every women either symptomatic or asymptomatic either showing any clinical finding or no clinical finding of cervix, who is capable of intercourse should be subjected to routine cytological examination.

\section{Correlation between cytology \& colposcopically directed biopsy}

In overall correlation both cytology and colposcopically directed biopsy showed correlation $81 \%$ in cases of SIL and $100 \%$ in case of invasive carcinoma.

Similar observations regarding accuracy were made by others:

Table 15: Correlation between cytology $\&$ colposcopically directed biopsy.

\begin{tabular}{|ll|}
\hline Observations regarding accuracy \\
\hline Benedict JL et al. & 82\% \\
\hline Adolf Stafl $^{11}$ & $92 \%$ \\
\hline Krishna Algotar $^{2}$ & $57.8 \%$ \\
\hline Mridul Gehlot & \\
\hline Present study & 93.33 \\
\hline
\end{tabular}

\section{Correlation between colposcopy and directed biopsy}

Overall correlation is good between colposcopy and histology with sensitivity of $94 \%$, specificity of $91 \%$ false -ve rate of $5.8 \%$, false +ve rate of $7.4 \%$ with accuracy of $92.85 \%$.

Colposcopy helps to reduce false -ve cases seen by cytology.

Similar observations regarding accuracy were made by others:

Table 16: Correlation between colposcopy and directed biopsy.

\begin{tabular}{|ll|}
\hline \multicolumn{2}{|l|}{ Observations regardling accuracy } \\
\hline Stafl \& Mattingly & $85 \%$ \\
\hline Krishna Algotar & $81.3 \%$ \\
\hline Benedict $(2001)^{16}$ et al. & $86.6 \%$ \\
\hline Present study & $83.3 \%$ \\
\hline
\end{tabular}

\section{Correlation between colposcopy and cytology}

Table 17: Correlation between colposcopy and cytology.

\begin{tabular}{|lll|}
\hline Sensitivity & $\begin{array}{l}\text { Cytology and } \\
\text { directed biopsy }\end{array}$ & $\begin{array}{l}\text { Colposcopy and } \\
\text { directed biopsy }\end{array}$ \\
\hline Specificity & $95 \%$ & $94 \%$ \\
\hline False -ve & $18 \%$ & $91 \%$ \\
\hline False +ve & $4.9 \%$ & $5.8 \%$ \\
\hline Accuracy & $92 \%$ & $7.4 \%$ \\
\hline
\end{tabular}


The above table shows high sensitivity in colposcopy as compared to cytology.

High false -ve rate with cytology will be reduced by colposcopy.

In some studies by different colposcopists, false +ve results were high. The major factor responsible for false +ve results include benign lesion of the cervix example, syphilitic ulcer, benign granulomatous lesion in which colposcopic differentiation from a malignant lesion is difficult \& sometimes impossible. As noted by coppleson, these lesions may represent epithelium with potential risk of malignancy and requires careful observations and follow ups for the possible SIL or carcinoma in situ in the future.

Cancer of the cervix continued as commonest type of cancer in India. The problem is not only of number but also of late diagnosis, majority being diagnosed in stage III and IV. Hence primary Goal is to "down stage" the disease meaning thereby that more and more number of cases should be diagnosed at an earlier stage. Cervical cytology can provide this but we do not have adequate resources to undertake mass cervical cytology.

According to expert colposcopist like Stafl and Mattingly (1985), cervical cancer of squamous cell type develops almost exclusively within the transformation zone as a result of atypical metaplasia. Since colposcopy allows precise evaluation of transformation zone, diagnosis as to whether cervix is normal or abnormal can be made accurately at time of examination and one does not have to wait for the report as in the case of Pap smear.

\section{CONCLUSION}

Cytology demonstrates the presence of premalignant and malignant lesions, whereas colposcopy shows the exact site for biopsy for histological diagnosis and for further management, combined use of cytology and colposcopy has enhanced diagnostic accuracy in preclinical lesions of uterine cervix. On the other hand histology must be touchstone of gynecological oncology practice and never be ignored.

Colposcopy and cytology are not competitive methods, but complement to each other in the early diagnosis of cancer. Colposcopy is a highly sensitive test but with low specificity, cytology has higher specificity but a low sensitivity. Best results in early detection of pre-invasive carcinomas could be obtained by combined use of cytology, colposcopy and colposcopically directed biopsies rather than any individual diagnostic technique.

The cytological screening should be carried out in all women above the age 18 years with or without symptoms to detect pre-cancerous and early invasive lesions, so as to treat them earlier and to avoid invasive carcinoma.

\section{ACKNOWLEDGEMENTS}

We would like to thank Dr. Kasturi Donimath, professor of obstetrics \& gynecology and Dr. U.S. Hangarga, Former HOD and professor of obstetrics \& gynecology, KIMS Hubli for their guidance, support and valuable expertise in conducting this study.

We would like to thank our families for their invaluable support and last but not the least, all the wonderful patients' and their attenders' for their cooperation and contribution.

Funding: No funding sources

Conflict of interest: None declared

Ethical approval: Not required

\section{REFERENCES}

1. Moscicki AB. Cervical cytology screening in teens. Curr Womens Health Rep. 2003;3:433-7.

2. Krislma Algotar, Atul Nalawade, Shivani Sachdev. Predictive value of colposcopy in cervical cancer screening. Bombay Hosp J. 2004 Jul;4603:1-9.

3. Gilbert TJ, Sugarman JR, Cobb N. Abnormal Papincolaou smears and colposcopy follow-up among American Indian and Alaska women in the Pacific North-West. J Am Fam Pract. 1995 MayJun;8(3):183-8.

4. Maya Lulla, Usha Saraiya. Colposcopic and cytological evaluation of cervical lesion. Indian $\mathbf{J}$ Cancer. 1983;20:156-60.

5. Nanavati MS, Mehta D, Ratnaparkhi S, Shroff R, Parikh M. Cervical intraepithelial Neoplasia. Indian J Obstet Gynecol. 1986;36(2):322-7.

6. Mridul Gehlot, Nupur Hoojja, Mahesh Kumar Lakhiwal. Correlation between colposcopy, cytology and histology in cervical lesions. J Obstet Gynecol India. 2001;51(5):180-3.

7. Allan B, Maclean MD, Mkcord. Cancer detectioncytology, colposcopy and cervical neoplasia. N Z Med J. 1985 Sep;28:757.

8. Malcolm Coppleson. Early invasive squamous and adenocarcinoma of cervix. In: Malcolm Coppleson, eds. Malcolm Coppleson Text Book of Oncology. 2nd ed. London: Churchill Livingstone; 1992: 632.

9. Kasper TA, Smith ESO, Cooper P. An analysis of the prevalence and incidence of gynecologic cancer cytologically. In: A. B. Miller, eds. Coppleson Text Book of Oncology. 2nd ed. London: Churchill Livingstone; 1970: 545.

10. Bharani Bharti. Role of colposcopy in evaluation of lower genital tract lesions in symptomatic women. $\mathbf{J}$ Obstet Gynecol India. 2004 Jul/Aug;54(4):372-5.

11. Adolf Stafl, Richard F. Colposcopic diagnosis of cervical neoplasia. J Obstet Gynecol. 1973 Feb;41(2):169.

12. Rekha Sapkhal, Shobhana Tehara. Detection of pathogenic organisms in chronic cervicitis by 
clinicopathology. J Obstet Gynecol India. 2000 Jun;50(3):65-9.

13. J. R. Van Nagell Jr, J. C. Parker Jr, L. P. Hicks, R. Conrad, G. England. Diagnostic and therapeutic efficacy of cervical conization. Am J Obstet Gynecol. 1975 Jan;124(2)134-9.

14. W. Kirkup, Shirley Hill. The accuracy of colposcopically directed biopsy in patients with suspected intraepithelial neoplasia of the cervix. BJOG. 1980 Jan;87(1):1-3.

15. Benedict JL, Matisic JP, Bertrand MA. Analysis of patients from the British Columbia cytology- colposcopy program. J Gynecol Oncol. 2004 Jan;92(1):127-34.

16. Benedict JL, Matisic JP, Bertrond MA. The quality of community coloposcopic practice. J Obstet Gynecol. 2004 Jan;103(1):192-9.

17. Fremont-Smith M, Graham RM, Meigs JV. The cytologic method in the diagnosis of cancer. New Engl J Med. 1948;238:179-81.

DOI: $10.5455 / 2320-1770 . i j \operatorname{rog} 20140967$

Cite this article as: Krishnegowda S, Veena MS.

Efficacy of colposcopy technique with Pap smear and histology in screening of cervical lesions. Int $\mathbf{J}$ Reprod Contracept Obstet Gynecol 2014;3:696-702. 